\title{
Communication and Action: Re-Reading Habermas in the Age of Activism
}

\begin{abstract}
The combined effects of digital communication technologies, political upheavals around the world, waves of powerful activism and protests have injected a new urgency into communication research. How communication theory is able to respond to this challenge is a matter of discussion, including the question of the adequacy of older theories to the new circumstances. This paper, aims to add to this discussion by returning to Habermas's pragmatics, one of the $20^{\text {th }}$ century communication classics, to reflect on how communication and other forms of action interact in campaigns for social change in the context of the growing reach of strategic communication and the growing role of social media in activism.

This article starts by posing theoretical disjuncture as a problem shared by a number of communication subfields, such as public communication, public relations, communication for social change, and my particular example, development communication. The more recent scholarship, however, has moved away from this state of knowledge. Instead, scholars highlight the need to embrace non-linear models of communication for social change, and appear to embrace hybridity to deal with the theoretical confusion in the field.

The analysis presented in this article aims to demonstrate that Habermas's communication pragmatics works well to explicate complex campaigning practices in a consistent and yet theoretically expansive way. Re-reading Habermas makes it possible also to respond to the call articulated by social movement scholars to move beyond the limits of strategy and to recognize the importance of larger cultural conversations and scripts. Conceptualizing public campaigning as chains of speech acts, defined here as both linguistic and nonlinguistic acts, offers an analytical tool that works across different levels, spaces, and actors involved in social change efforts and that privileges communication as the explanatory mechanism for the contemporary social change praxis.
\end{abstract}

* Queen Margaret University. 
Finally, returning to Habermas's work underscores the importance of a valid position, rather than a desirable identity, from which to engage with others in the social world. This invites a clear and consistent focus on action and its basis (moral position) rather than on attributions ascribed to organizations and campaigners (identity). The key question thus shifts from 'Do you like me/trust me sufficiently follow me?' to a more substantial, 'Is this a good thing to do?'

Keywords: theory of communication action, social change, campaigning, strategic communication, development communication.

\title{
Komunikacja i działanie: odczytywanie Habermasa na nowo $w$ dobie aktywizmu
}

\begin{abstract}
Abstrakt
Technologie komunikacji cyfrowej, światowe wstrząsy polityczne, fale silnego aktywizmu i protesty spowodowały, że badania nad komunikacją znów stały się niezbędne. Można dyskutować, jak teoria komunikacji jest w stanie odpowiedzieć na to wyzwanie i czy stare teorie są adekwatne w stosunku do nowo zaistniałych warunków. Niniejszy artykuł jest w zamierzeniu częścią tej dyskusji i zwraca się ponownie do pragmatyki Habermasa, jednego z klasyków komunikacji XX w., aby podjąć refleksję nad tym, jak komunikacja i inne formy aktywności oddziałują na siebie w kampaniach dotyczących zmian społecznych, w kontekście rosnącego zasięgu komunikacji strategicznej oraz rosnącej roli mediów społecznościowych w aktywizmie.

Artykuł zaczyna się od przedstawienia teoretycznego rozłamu jako problemu wielu podobszarów komunikacji, takich jak komunikacja publiczna, PR, komunikacja dla zmiany społecznej oraz komunikacja rozwojowa, którą opisuję jako szczególny przykład. Nowsze badania odstąpiły od tej problematyki. W zamian badacze podkreślają potrzebę przyjęcia nieliniowych modeli komunikacji dla zmiany społecznej i decydują się na przyjęcie hybrydowości jako rozwiązania teoretycznego zamętu w ramach tej dziedziny.

Celem analizy przedstawionej w niniejszym artykule jest wykazanie, że pragmatyka komunikacji Habermasa dobrze objaśnia skomplikowane praktyki prowadzenia kampanii w sposób spójny, a także ekspansywny teoretycznie. Odczytanie Habermasa na nowo umożliwia również udzielenie odpowiedzi na postulaty wysuwane przez badaczy ruchów społecznych, aby wyjść poza granice strategii i uznać znaczenie szerszych konwersacji i skryptów kulturowych. Konceptualizacja publicznych kampanii jako ciągów aktów mowy, zdefiniowanych tutaj jako akty językowe i pozajęzykowe, daje nam narzędzie analityczne do pracy na różnych poziomach, w różnych miejscach oraz z różnymi aktorami zaangażowanymi w działania promujące społeczną zmianę, a także uprzywilejowuje komunikację jako mechanizm wyjaśniający współczesną praktykę zmiany społecznej.

I wreszcie, powrót do dzieł Habermasa podkreśla znaczenie uzasadnionej pozycji, z której wchodzimy w reakcję z innymi w świecie społecznym, stawiające ją ponad pożądaną tożsamość. Zachęca to do poświęcenia uwagi działaniu i jego podstawie (pozycji moralnej), a nie atrybutom przypisanym organizacji i działaczom
\end{abstract}


(tożsamość). A zatem, nacisk przesuwa się z pytania „Czy lubisz mnie/ufasz mi wystarczająco, aby za mną podążyć?” na ważniejsze pytanie „Czy to jest dobre działanie?".

Słowa kluczowe: teoria działania komunikacyjnego, zmiana społeczna, kampanie, komunikacja strategiczna, komunikacja rozwojowa.

\section{Introduction}

Communication and its political and social role has been studied by several generations of communication and media scholars (Mihelj, Stayner 2019; Scannell 2007). Yet the combined effects of digital communication technologies, political upheavals around the world, waves of powerful activism and protests have shaken up the discipline and injected a new urgency into communication research. How communication theory is able to respond to these changes is a matter of discussion, including the question of the adequacy of older theories to the new circumstances (Neuman 2016). This paper aims to add to this discussion by returning to Habermas's pragmatics, one of the $20^{\text {th }}$ century communication classics, to reflect on how communication and other forms of action interact in campaigns for social change in the context of the growing reach of strategic communication (Hallahan et al 2007) and the growing role of social media in activism (Bennett, Segerberg 2012).

The starting premise for this discussion is that communication has social consequences and, thus, the way in which it is conducted raises questions of its effects, effectiveness, and ethics. This paper is organized into four sections followed by concluding remarks. 'Communication for social change: the dilemma' introduces the problem pursued in this discussion: the tension between top-down and groundup approaches to the use of communication in campaigning for social change. Persuasive and social communication practices, whether public communication, public relations, advocacy, strategic communication or communication for social change have had to grapple with the difficulty posed by Habermas's distinction between communicative and strategic action: using communication to create understanding and consensus or employing communication to achieve desirable outcomes by engineering compliance. The following section, 'Using language to act: linguistic and nonlinguistic action' considers the interaction between communication and other forms of action in the specific context of campaigning for social change. The following two parts of the discussion, 'Communicative vs strategic action' and 'Campaigning praxis in the light of speech acts' introduce the key concepts from Habermas's theory and then apply them to examples of contemporary campaigns for two reasons: Firstly, campaigns are reinterpreted in terms of communication rather than social movements theory. Secondly, an attempt is made to test the extent to which a more nuanced reading of Habermas's treatment of 
'perlocution' resonates with the reconceptualization of the role of communication in the field of development, and, by extension, communication for social change (Wilkins et al. 2014).

\section{Communication for social change: the dilemma}

The key dilemma in the field can be summarized as the tension between two paradigms: persuasion versus dialogue; pre-defined goals that drive communication efforts in campaigning versus an enabling critique and co-creation of goals; individual change linked to the logic of diffusion of innovations versus participation understood in terms of Freirean pedagogy (Tufte 2017).

The way in which communication as a discipline has approached the question of how the use of language underpins the functioning of the social world owes much to the philosophy of language and specifically Habermas's Theory of Communicative Action. Yet while Habermas focused on communication as the mechanism for consensus buidling that undeprins collective action, the rhetorical traditon privileges persuasion as the route to action. Overall, research on public campaigns tends to focus on three aspects: on the campaign's reception; on the campaign structure, process and management; and finally, on the rhetorical or discursive aspect, which highlights specific social features of the use of language. The first, reception, treats communication as a stimulus that produces specific cognitive, affective, or behavioural outcomes and, consequently, it attempts to establish stable and predictable patterns in which these occur (for example, Witte 2000). The second approach sees communication as a sequence of expert actions that combine research, definition of the target groups, choice of message strategies, attention to channels and timeliness of messaging, and the evaluation of outcomes in relation to the campaign goals (Rice, Atkins 2013). Finally, the third approach critically examines the production of texts by looking to systems of meaning and to power dynamics of discourse in order to explain the change sought or produced (e.g. Gamson, Modigliani 1989; Fairclough 2000; Fochtner, Krzyzanowski, Wodak 2013). Similarly, in development communication, there is a strong focus on strategic approaches and persuasion as mechanisms for change and, historically, there is also a rigid distinction between the strategic/persuasive understanding of communication and the participatory, dialogical paradigm (Waisbord 2014).

This overview suggests that campaigning for social change is understood predominantly in terms of its ability to produce desired effects which are defined by the campaign goals. This technical interest in the production of persuasion and the resulting action can be contrasted with Habermas's attention to the processes of meaning production and the lifeworld. For Habermas 'new social movements are located at the intersection of system (economy, the state) and life-worlds, where they react to colonization tendencies' (Lahausen 1996: 6). In this sense, social 
movements and activism, and by extension social change campaigning, spring from a challenge to the existing normative order and its institutionalization (Schmidt 2012: 104). At the core of what social movements do lies the need to articulate the challenge to such normative orders and their institutions.

Such a tension between different approaches to communication can easily be translated into Habermasian terms. On the one hand, campaigning for social change as communication seems to be understood in terms of goal orientation (strategic action), yet it can evade this classification as purely strategic action by the nature of its location in the lifeworld, resisting and challenging the established order of the system (communicative action). Strategic communication is often seen as disempowering individuals, serving to colonize the lifeworld, and consequently treated with suspicion (Torp 2015: 47-48). If campaigning is largely underpinned by a social marketing model of targeted persuasion aimed at achieving knowledge/ attitude/ behaviour change at the individual level to engineer desired change, it can also be seen as explicitly concerned with patterns of collective behavior and mutual understanding (communicative action), thus directing our attention to the nature of connections and relationships enacted through campaigns. It is these two seemingly contradictory impulses-to create effective, disciplined action and to focus on critical reflection with its inherent freedom and resistance mechanisms (see also Sennett 2012) - that this paper aims to investigate in more detail by returning to Habermas's own theory of communicative action and, in particular, to his treatment of perlocution, roughly equivalent to persuasion, where he appears to soften the rigid conceptual boundary between communicative and strategic action.

\section{Using language to act: linguistic and nonlinguistic action}

The purpose of this section is to lay out my understanding of what constitutes action in the context of campaigning for social change, specifically to illustrate the distinction between action that is performed through language and forms of action that do not depend on language as part of their performance. Throughout the paper, illustrations will be drawn from real-life campaigns to sharpen up the thinking based on Habermas's concepts of communicative and strategic action and on his treatment of perlocution. Examples used here come from three sources. Insights into Occupy London praxis are drawn from material accessible via the movement's website and other publicly available online content at the time when the camp occupying the space in front of St Paul's Cathedral was still in place ${ }^{1}$ and on some of its later activities that encompassed the work of organizing both the people and the space. A deliberative event Thinking Together, A Citizens Assembly

\footnotetext{
1 The original camp occupied the space in front of St Paul's Cathedral in the centre of London. It was cleared on 28 February 2012, following an eviction order obtained by the City of London Corporation. See http://www.theguardian.com/uk/2012/feb/28/police-evict-st-pauls-occupy-protesters
} 
organized by So Say Scotland is used less extensively in this discussion, but the example also utilizes online materials as well as the author's knowledge as one of its facilitators. Finally, examples are also drawn from the website of Anti-Slavery, a campaigning organization, established in 1839 and dedicated to eliminating 'all forms of slavery around the world' (http://www.antislavery.org/english/what we_do/default.aspx).

Occupy London is part of the worldwide Occupy protest movement which started in New York in September 2011 in the wake of the 2008 financial crash. Its broad goal is to protest against the social and economic inequality that arose in a democratic system corroded by 'the power of major banks and multinational corporations' (Occupy Wall Street). Occupy London, part of the global Occupy Movement, was launched soon after New York. Its overall goal was articulated in the first point of the Statement the movement agreed on 26 October 2011: 'The current system is unsustainable. It is undemocratic and unjust. We need alternatives; this is where we work towards them' (Occupy London Statement).

From the minutes of the General Assembly, constituted as the main decision making body for the movement, dated 8 November 2011, we can identify specific actions undertaken by the protesters: the Finance Working Group (WG) opened a bank account and was ready to deal with small expense claims; Outreach WG was working on a leaflet; Lord Mayor's Show WG was organizing an afternoon of comedy and music and looking for volunteers who could do face painting or ride a unicycle; and, finally, that the Sanitation WG-which was also looking for volunteers-announced a schedule for cleaning the site, starting at 10 o'clock from the Cathedral steps and then moving on to the Portaloos ${ }^{2}$.

A deliberative event such as the Citizens Assembly illustrates how talking about experiences and ideas, listening to others, questioning, and writing a new statement of shared values, thus communication itself, can constitute action. On the other hand, the example of Occupy London activities demonstrates how communication intersects with, or is auxiliary to, nonlinguistic forms of action, such as face painting or the cleaning of portable toilets. It also shows how non-deliberative forms of communication, encapsulated in texts or artifacts (e.g. leaflets or websites) also constitute action. Finally, the toilet cleaning example shows that action may be achieved with minimal or no use of language. Moreover, such an activity constitutes action for social change only if it is recognized as a contribution towards creating an alternative to the current unjust democracy. In this case, this interpretation is derived from the nature and occupancy of the space, defined normatively by the explicit and shared stance articulated in the Statement referred to earlier. Thus, people who clean the toilets are not toilet cleaners, but activists. Tempting as it is to joke here, cleaning the Portaloos is a rather impressive gesture of solidarity as it

\footnotetext{
2 This information was drawn from http://occupylondon.org.uk/occupylsx-general-assembly-minutes8112011-7pm/ [accessed: May, 2014].
} 
recognizes the presence and needs of other people in the most selfless and direct way, by undertaking tasks we do unpaid usually only when caring for people closest to us.

While the focus so far has been to illustrate linguistic and nonlinguistic action, the examples have been drawn from campaigns encompassing many such individual activities. A campaign here is consequently understood as an extended and coherent unit of goal-oriented action constitutive of 'the mobilization praxis of contemporary social movement organizations' (Lahusen 1996: ix). A campaign weaves together 'activities and communication geared to effect...social change' (ibidem: $x$ ). Campaigns use communication to explain and popularize their goals, to mobilize support, and to initiate action. Communication, thus, gives a campaign its shape: it frames the cause, or as I have referred to it so far-the challenge; it makes its audience and its supporters through forms of address and communication channels used; and it facilitates action, which may be performed as communication or other kinds of activity.

Communication as action, i.e. doing things by communicating, can take communicative and strategic forms-that is, it can focus on achieving mutual understanding or on other goals, such as getting others to perform specific actions. Communication as action can be exemplified by commonly used campaigning tactics, such as: writing to Parliamentary/elected representatives or other officials, signing petitions, tweeting; or by collaborative work that produces statements of values or policy proposals that articulate the desired change. A good example of the latter is a deliberative event, Citizens Assembly, organized by So Say Scotland ${ }^{3}$ in February 2013 to produce a grassroots view of Scotland as a democratic country at the time when the road to the referendum on Scottish independence (which took place in September 2014) had been cleared by the Privy Council ${ }^{4}$. Occupy London has already supplied some examples of nonlinguistic action; other popular forms of nonlinguistic action include: (non)consumption, political participation, or forms of philanthropy. The repertoire of nonlinguistic action thus includes: exercising consumer choice in relation to social relations and governance systems embedded in goods by buying locally produced food, or refusing to buy garments produced by child labour; by voting in elections; or by donating resources such as money, time or expertise and collaborating with others to create, for example, infrastructure, such as water supply systems or schools to change people's lives.

From the perspective of social change praxis, then, action might be defined by three characteristics attached equally to linguistic and nonlinguistic activities by

\footnotetext{
${ }^{3}$ So, Say Scotland is a non-profit organization devoted to democratic reform in Scotland, see https:// www.facebook.com/sosayscotland/. For more on Thinking Together, A Citizens Assembly, see http://issuu.com/sosayscotland/docs/sosayscotland-treasuretrove-thinkin

${ }^{4}$ Scotland Act 1998 (Modification of Schedule 5) Order 2013 introducing an appropriate modification to the relevant legislation on devolution of powers between Scottish and the UK governments and parliaments. See http://www.bbc.co.uk/news/uk-scotland-scotland-politics-20546497
} 
those who perform them and those who see them being performed. Firstly, it is meaningful within a particular normative framework. Secondly, it makes a specific contribution to the achievement of explicit (and shared) goals. Thirdly, it is a gesture of solidarity and, at the same time, of challenge-it acknowledges the connection to others by virtue of performing the activity and thus also reiterates the challenge posed by the campaign to the existing order.

A further theoretical conclusion to draw from this discussion is that communication is related to other types of action in three possible ways. Firstly, linguistic action is enmeshed with nonlinguistic action in routinized or scripted sequences (for example, the business interaction needed to open a bank account). Secondly, linguistic action serves to trigger further linguistic and nonlinguistic action in situations where alternative scripts are possible (persuading people to deliberate; to volunteer to ride a unicycle or clean toilets when they can choose to demonstrate their engagement by other means). Finally, the act of communication itself can constitute action (deliberating on what democratic governance should look like in Scotland) 5 .

This section has demonstrated that campaigns for social change consist of complex chains of actions/activities that may involve communication (doing things with language) as well as other forms of acting (that may not depend on language use). The purpose here was to prepare the ground for the discussion of Habermas's conceptual framework for linguistic forms of action (communicative and strategic) before moving on to the discussion of perlocution, a concept that focuses on ways in which language creates effects and makes things happen.

\section{Communicative vs strategic action}

In The Theory of Communicative Action (TCA), Habermas turns to the question of language and action by taking a pragmatic approach and building his theory directly on the work of two philosophers of language, J. L. Austin and John Searle, who proposed and elaborated the theory of speech acts. I do not intend to present an extensive overview of Habermas's theory, but rather to offer sufficient explanation of some of its key aspects to allow me to concentrate on its applicability to social

\footnotetext{
5 This distinction brings to mind Habermas's distinction between institutionally bound and institutionally unbound speech acts. The first derive their meaning from the logic and norms of specific social institutions, for example, speech acts of christening a baby or of betting derive their meaning from the institutions of christening and betting (Habermas 1976/2002: 60). Institutionally unbound speech acts, such as, 'commands, advice or questions do not represent specific institutions ... and can fit very different institutions' (ibidem: 61). While institutions often prescribe either very specific communication scripts (e.g. a marriage ceremony) or at least rough outlines of such scripts (obtaining advice from your doctor in the context of a consultation), I wish to note the existence of such scripts, for example, for advice giving or expressing requests more generally, when their link to specific institutions might be rather loose.
} 
change campaigning and on its implications for thinking about the interrelations between communication and other types of action in this specific context.

The starting point to this brief exposition is Searle's view that 'speaking a language is engaging in a rule-governed form of behaviour' (Searle 1969: 22). This makes it possible to place communication conceptually in the same broad category as other forms of behaviour ${ }^{6}$, which I have done in the preceding section in relation to the constitutive elements of a campaign. The fact that behaviour is defined as 'rule-based' has a number of implications, the most salient here being that rules provide the social connection of intelligibility between people. Speech acts are defined as utterances produced in accordance with such rules that perform acts such as asking a question, giving a command, making an assertion about things (ibidem: 16-25). To put it simply, a speech act is an instance of the use of language that does a particular job. A fundamental distinction made in speech act theory, and one retained in $T C A$, is that between illocutionary and perlocutionary acts:

Through illocutionary acts the speaker performs an action in saying something.... "I hereby promise you (command you, confess to you) that....". (...) Through perlocutionary acts the speaker produces an effect upon the hearer. By carrying out a speech act he brings about something in the world (Habermas 1984: 289).

Habermas is keen to establish and elaborate the distinction between communicative action-defined by its illocutionary nature and, thus, the orientation to reaching understanding-and perlocution, which is goal-directed and considered 'a special class of strategic action' (1984: 293). Yet his main interest lies in exploring linguistic mechanisms that underlie the process of reaching understanding which, in turn, produces binding obligations that trigger appropriate action, for example, joining a protest. In his later essays (1988/2002; 1996/2002), Habermas returns to the question of how communication as a form of action produces effects, and he develops the concept of perlocution in more detail, thus probing the boundary between communicative and strategic action as well as between linguistic and nonlinguistic action. In order to follow the nuances of this later elaboration, a basic exposition of the relevant elements of the theory will now be offered.

A key feature of TCA is the way in which it maintains sensitivity to the complexity of social life, i.e. to the different levels, domains and contexts of using communication as action by establishing, as the starting point, the 'threefold relation to the world of communicative agents' (Habermas 1984: 99): to the objective world; to the social world of 'legitimately regulated interpersonal relations'; and the subjective world of personal experiences to which the speaker has privi-

\footnotetext{
${ }^{6}$ For stylistic reasons, I use here the term behavior, but treat it as synonymous with action. For reasons of brevity, I do not offer further discussion of this point based on Weber's differentiation between the two terms.
} 
leged access (ibidem: 100). All of these are contained in a speech act. These three domains give rise to three types of validity claims on which agreement or disagreement between interlocutors rests: truth, rightness, and truthfulness/sincerity. The process of reaching understanding in communication, thus, hinges on the acceptance or rejection of the validity claims contained in, or as Habermas puts it, raised by utterances.

Let's take the example of Occupy London's explanation Occupy London Statement http://occupylondon.org.uk/about-2/ [accessed: 28.05.2014] of its purpose, quoted above: "The current system is unsustainable. It is undemocratic and unjust. We need alternatives; this is where we work towards them". For the purpose of this analysis, let's interpret it as a call to action. Such a speech act might take the following form:

- We ask you to join us in creating alternatives to the unjust and unsustainable democracy we live in, to which one may respond: Yes, I will, thus accepting an obligation to act.

As a speech act, this is a request to join the movement. This utterance contains an assertion about the world (it is unjust and unsustainable); and it also hints at the world of personal experiences ${ }^{7}$ which are not directly accessible to the hearer. The response of "Yes" can, therefore, be seen as an agreement with the following three questions that represent the three types of validity claims raised here:

- Do you agree that the current form of democracy is unfair and unsustainable? (Truth)

- Do you agree that it is right/appropriate for us to make this request of you? (Rightness, appropriateness, i.e. normative validity)

- Do you agree that we are sincerely concerned with the state of democracy? (Truthfulness/Sincerity).

The agreement constituted on all three aspects of validity, defines communicative action. Habermas offers such communicative agreement as a model of rationality.

Thus, communicative action with its illocutionary orientation represents communicative rationality; whereas perlocution/strategic action, which is not constituted by such validity claims, but is instead accepted or challenged on the basis of its effectiveness, is characterized as irrational. In this example, a strategic approach would focus on the assessment of whether joining the protest action is the most effective way to achieve the goal of change. We find such a strategic interpretation of Occupy London expressed by some of its critics who saw it as

\footnotetext{
7 For the sake of clarity and simplicity, I shall not make a distinction between individual and organizational speakers at this point in my argument.
} 
a failure-ineffective because of its 'incoherent' and unrealistic goals (i.e. ways of going about system change): 'Certainly their rhetoric at the start about sweeping changes to the financial sector was unrealistic and was never going to happen' (Cacciottolo 2012). Those who supported the protest saw such strategic criteria as unimportant and instead interpreted the events-the St Paul's protest camp-as communicative action, as a successful illocutionary act constituted through collective action:

It doesn't matter whether the tents are there or not, ... it doesn't matter if we're able to camp there. What matters is we've been able to come together and meet a lot of people who have all formed networks, both nationally and internationally, to make our voices heard against the crisis which the banks have created and the corporate greed (ibidem).

If initially in TCA illocutionary and perlocutionary/strategic speech acts (doing by saying, vs. saying to get things done) are clearly separated, they soon become more of a tangled problem, as indicated by Habermas in his more detailed discussion of speech acts (1984: 284-325; Smith 1997: 108). He returns to perlocution as something of an unfinished business in his later essays, 'Actions, speech acts, linguistically mediated interaction, and the Lifeworld' (1988/2002) and particularly in 'Some further clarifications of the concept of communicative rationality' (1996/2002). The absolute demarcation between communicative and strategic action begins to lose some of its sharpness once a more detailed account is offered of the processes of reaching understanding and of perlocution ${ }^{8}$ (Baxter 2011: 16). On the face of it, this may sound a rather heretical position to take given Habermas's repeated and explicit separation of communication oriented towards reaching understanding (communicative action) and action oriented towards consequences other than understanding (strategic action). Yet, I want to argue that there are grounds in Habermas's own writing to work with these ideal-type constructs in a more pragmatic way, highlighting the complexity of social action such as campaigns for social change, as well as acknowledging a level of openness and choice available to those who encounter such campaigns as to the mode of their engagement.

My argument here follows Habermas's more nuanced explanation of both communicative action itself, and the way in which communication in either of the two forms can be "stitched to" actions that follow. Firstly, communicative action can now take one of two forms: strong, with all validity claims being accepted, which Habermas labels as agreement; or weak, where only claims of truth and truthfulness/sincerity are accepted-this Habermas calls understanding (Habermas 1996/2002: 332). Secondly, perlocution is now presented as a range, starting with

\footnotetext{
8 "'Perlocution" is, of course, the name we give to the effects of speech acts that, if need be, can also be brought about causally by nonlinguistic action' (Habermas 1996/2002: 329).
} 
effects that follow directly from the illocutionary achievement and ending with strategic action where effects are produced by systematically distorted communication, that is, communication which not only blocks routes to consideration of validity claims, but may also obscure the desired effect itself in order to make it happen (Habermas 1976/2002: 93; 1988/2002: 222-223).

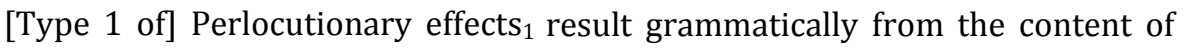
a successful illocutionary act-as when a valid command is executed, a promise is kept, a declared intention is realized, or when assertions and confessions consistently fit with the subsequent course of interaction. ... [Type 2] Perlocutionary effects 2 are grammatically non-regulated, that is contingent, consequences of a speech act that, however, occur only as a result of an illocutionary success-as when a piece of news, depending on the context, delights or startles the receiver, or when an imperative encounters resistance, a confession awakes doubt and so forth. Finally, perlocutionary effect ${ }_{3}$ [Type 3] can be achieved only in a manner that is inconspicuous as far as the addressee is concerned: the success of this strategic action of a kind that remains latent for the other party-is also dependent on the manifest success of an illocutionary act. (Habermas 1996/2002: 330)

There are three points to take away from this discussion. Firstly, there is more than one form of illocutionary success-strong and weak. In practical campaigning terms, the question that arises here is about the consequences of this distinction for the resulting action: do different forms of communicative action lead to different consequences? Secondly, illocution and perlocution are not necessarily mutually exclusive, but rather co-present in different configurations. In other words, while understanding or agreement are entirely cut off from persuasion and actions that follow, perlocutionary effects (strategic action) depend on some degree of illocutionary success (Habermas 1996/2002: 223). Thirdly, the interrelations of understanding and successful persuasion may depend on the way in which participants engage in the communication game: the stances they adopt throughout interactions and the ways in which they read the actual forms of language they encounter, as opposed to their idealized forms on which the Habermas's framework rests. The following section will examine these ideas in the context of campaigning for social change.

\section{Campaigning praxis in the light of speech acts: Illocutionary and perlocutionary effects}

In this section, Habermas's ideas introduced above are applied to interpret real-life, complex examples of the interaction of communication and other forms of action in pursuit of social change. The first part of this section shows that campaigning for 
social change can be understood as an opening of multiple simultaneous conversations where linguistic action triggers a range of different commitments to ensuing action (including rejection). The second part of this section interprets campaigns not as a linear development of strategic action, i.e. change that unfolds in a controlled way triggered by communication, but rather as multiple long chains that weave together communicative and strategic action as well as nonlinguistic actions that follow from them.

The previous section of this paper offered a model of what a strong illocutionary effect might look like in the case of Occupy London. If we accept this model, we can view the 100 occupiers and 200 supporters present when the eviction of the camp took place as acting on the obligation resulting from the agreement with the call to protest. Communicative action thus led directly to the fulfillment of the accepted obligation to act. However, there is also evidence of a different illocutionary process at work. David Green in his New Statesman blog, An Open Letter to the St Paul's Protesters (24 February 2012) writes: 'I will be sorry to see you go. I work in the City of London, and I have walked past your tents most days [emphasis added]'. He then goes on to say:

Just by staying put you shoved those in power into uncomfortable and telling predicaments. ...And you have been decent and polite throughout your stay. The camp has applied health and safety measures which show a genuine care for yourselves and those who could be affected by you. There has been sincere and often constructive engagement on various issues with bankers, lawyers and other City workers. ...But the great achievement of "Occupy LSX" was never the physical camp: It was the realisation that those in power can be wrong-footed, and that their bullshit can be exposed, by those who are serious and thoughtful about promoting a better world. This can be done anywhere, and not just in a churchyard of a Cathedral.

We can point here to the validity claim being accepted at the levels of truth (agreement on the destructiveness of capitalist institution) and truthfulness ('serious and thoughtful') thus suggesting a weak form of communicative action. It is also clear that the writer did not join the protest. The question then is whether the link between accepting an obligation and following through with an appropriate action is as direct as Habermas assumes. Let's examine this question in some more detail.

A YouGov poll conducted on 28-29 February $2012^{9}$ offered some useful material: $43 \%$ of those surveyed agreed with the aims of the protest action, irrespective of their position on the rightness of the protest camp itself; $66 \%$ thought that the eviction of the camp was the right decision and $26 \%$ disagreed with the aims

\footnotetext{
9 The survey was conducted on a sample of 1,778 British adults (25-60+) drawn from across England and Scotland. (http://cdn.yougov.com/cumulus_uploads/document/vb5ebifzi7/Copy\%20of\%20Results\% 20120229\%200ccupy\%20London.pdf).
} 
of the protest. While the first figure can be interpreted as a statistical illustration of the split between weak and strong communicative achievement-not all who supported the aims supported the methods; the latter pair of figures might suggest the extent of the disagreement not only on the methods appropriate for the social change sought, but also on the view of the world that is offered by the protesters (truth).

Another way to approach the question of the link between campaigning as speech acts and the actions they bring about in this example is to ask what the protest achieved. YouGov's website carried some relevant data and analysis: 71\% of their survey respondents (see above) thought the protest achieved little or nothing, while 15\% thought the opposite. Qualitative comments from this survey offer more insight into what is behind these numbers, i.e. how people engaged with the statement made by Occupy London, as well as with its ten-point Statement (http://occupylondon.org.uk/about-2/). YouGov summarized these views as a list of statements, the negative ones being: 'nothing has changed; they had a bad reputation; it was too disorganized and unclear; they alienated their sympathisers; they didn't get enough good publicity, the public are "fed up" of protest' (http:// yougov.co.uk/news/2012/02/29/occupy-london-what-impact-has-it-made/). Interpreting them in terms of validity claims shows that validity was challenged at the level of truthfulness: "I feel the protesters were not genuine victims of the recession but trained activists and troublemakers"(Rosie B, South London in: ibidem).

Validity was also challenged on the level of rightness, specifically by ascribing particular views or characteristics to the protesters that apparently made it illegitimate for them to protest against the system:

- The majority of them shown on TV looked like long haired dropouts. Have they not got jobs to do, and families to support, or are they living off tax payers like myself?" ( Lesley, South Yorkshire, in: ibidem);

- Usual bunch of crusties who protest about everything. Would have been nice to see a cross section of people, but I guess they are all too busy running on the treadmill to stay in the same place (John B, East Sussex, in: ibidem).

We also see an attack on the methods, which constitutes a kind of normative challenge (rightness):

- They hardened my attitude toward this sort of lawless, anti-social behaviour! I'm sick of the Government, authorities and media pandering to such obvious law breakers! It's my hard earnt taxes they were spending! (Mike, South West, in: ibidem). 
Finally, there is evidence of responses to Occupy London that interpret it as a failed strategic action on the grounds of its ineffective methods (rather than their inappropriateness in the normative sense):

- Just wasn't handled in the right way. They came across as mad, lefty activists claiming to represent "the people". Better methods could have been followed' (James, London, in: ibidem)

- You can't change the world with tents (Pete, Coventry, in: ibidem)

or on the grounds of failure to achieve stated goals:

- Nothing has changed. The system will still work in the same way it always has (DC, Walsall, in: ibidem).

A relevant example of a strategic reading of the protest comes from Don Hodges's blog in Total Politics (28 October 2011). The author is presented as a professional (a campaigner for 'Labour, the trade unions, private and charity sectors') bewildered by the ways of the protest camp that break the cardinal rules of communication management: he asks what the message is, and gets six different answers; the mission statement is illegible; there is no press office, and the press officer is rather elusive-in short, 'pretty poor trade craft' is his judgment. The failure is quite clearly attributed to the nature of the organizational form adopted-grassroots, open, nonhierarchical. The protesters themselves say: 'as an organisation we've grown organically', '...we're not managed from the top down [people] tend to gravitate towards the things that interest them' (Hodgson 2011).

What these examples show is that the speech act can elicit a range of different responses: the same opening gambit may lead to different simultaneous 'conversations' developing, triggering chains of further action. We can see levels of success in communicative action; but we can also see different ways of interpreting the intention behind the campaign and engaging with it as a speech act. While some see it as oriented towards co-operation to underpin change (performative attitude); others read it as oriented towards achievement of stated goals (strategic) and regard it as a failure. In his model of how language constitutes action, Habermas offered great conceptual clarity, but the price for this clarity is the distance it puts between the theory and the messiness of the phenomenon it dissects and reassembles as disciplined knowledge.

The next section aims to shorten the distance between theory and practice by considering campaign communication praxis not as selected specimens, such as the narrowly focused examples presented so far, but rather as larger and messier patterns of actions, or simultaneous conversations. I attempt to explore an idea whose presence is marked in TCA and articulated in 'Some further clarifications of 
the concept of communicative rationality' (1996/2002), namely, that to understand human action is to see it as something of a patchwork, a pattern formed by the interlocking of different types of action.

\section{Social change campaigns as chains of speech acts}

Occupy London was a grassroots, open, and undisciplined (in a Foucauldian sense) type of organization; Anti-Slavery International, on the other hand, can be seen as dramatically different in its approach to organizing. First of all, it is institutionalized through its official status as a registered charity in the UK with its clear official statement of aims and of its finances. Anti-Slavery has employees, volunteers, offices in London, and an annual income of just under $£ 3$ million (in 2018), nearly two thirds coming from institutional donors and earmarked for specific activities ${ }^{10}$. It operates within a network of established organizations such as the International Labour Organization, (ILO); the International Trade Union Confederation, (ITUC); human rights organizations such as Liberty and Amnesty International; and it can obtain access to formal policy making processes, for example by gaining support from officials such as George Sabin Cutaş, an MEP who was the rapporteur in the EU parliamentary debate on the EC-Uzbekistan partnership and cooperation agreement on bilateral trade in textiles on 14 December 2011 and made an explicit promise to put Anti-Slavery's work forward for consideration in future EU policy making processes ${ }^{11}$.

Like many international campaigning organizations, Anti-Slavery depends, on the one hand, on a set of activities ${ }^{12}$ such as campaigns focused on specific or local iterations of the main issue of slavery (e.g. domestic slavery, forced and bonded labour, trafficking; Cotton Crimes in Uzbekistan; a Chocolate/cocoa campaign in Ivory Coast; a fishing industry campaign in Thailand). On the other hand, it also carries out more generic activities, such as fundraising, education, outreach, and research. To shed more light on the pattern of this organization's overall action, it is useful to start with a specific campaign, such as Cotton Crimes, directed against the use of child and forced labour in cotton harvests by the government of Uzbekistan.

I argue that it is possible to see this campaign as interrelated speech acts: if we treat Cotton Crimes as an illocutionary act of request for support, its other elements identified on the relevant page of the website-Background Information, Cotton Crimes Video, Write to MEP and Write to Daewoo-can be seen as both speech acts

\footnotetext{
${ }^{10}$ See https://www.antislavery.org/wp-content/uploads/2019/03/Anti-Slavery-Accounts-2017-18.pdf

${ }^{11}$ See http://www.europarl.europa.eu/sides/getDoc.do?pubRef=-//EP//TEXT+CRE+20111214+ITEM$018+\mathrm{DOC}+\mathrm{XML}+\mathrm{V} 0 / / \mathrm{EN}$

${ }^{12}$ Unless otherwise indicated, all the details used in the discussion of Anti-Slavery come from the organization's website http://www.antislavery.org/english/ accessed regularly between June and October 2014.
} 
in their own right, and also as acts that follow from the initial request. For example, Background Information, presented in the form of an argument for why intervention/action is needed, can be seen as a constative type of speech act: it makes an assertion about the objective world, e.g. the use of children and other forced labour, the way that practice works, the market value of its product, and the way in which the government flouts its obligation to ensure fair labour practices. The links to research and evidence referred to at the bottom of that particular page can be seen as offering further support to this assertion. The short Video contains a visual representation of the key argument: it makes a connection between the practices of consumption of luxury cotton goods in the West and the injustice and force involved in the production of such goods. By sharing this video through social networks, which viewers are asked to do, another action is added to this chain: a request to inform others about this state of affairs. Thus, while Background Information can be seen as creating the knowledge on which the claim of truth for this campaign can be settled, the organisation's history (Our History) and its Annual Reports going back to 2008 (Resources) can be seen as supporting its claim to truthfulness. The challenge on normative grounds (rightness) is anticipated with the abundant case study material across many pages of the site: people who have experienced slavery giving first-hand accounts, highlighting the brutality, poverty, and indignity inflicted on victims of slavery. These are expected to contrast not only with the life experiences of many readers, but, perhaps more importantly, with their ideas of justice and human dignity. Case studies typically take the form of expressive speech acts (a first-person account, the speaker referring to his/her own experience, the aim being that of self-representation) and the validity claim that settles this type of action is the truthfulness of the account. Thus, readers need only accept that this is truly the account of the person who speaks, the narrative ' $\mathrm{I}$ ', and that the narrator is faithful to his or her experiences.

The final example I wish to consider here is that of a common mobilization strategy, a letter writing campaign used in this context to put pressure on the addressee: the Write to Daewoo campaign. The company is singled out as the largest processor of Uzbek cotton. A draft letter to the company's chairman is supplied so that the action requested need not involve more than supplying one's own details and sending the letter. The speech act is, again, that of a request-to write to Daewoo obliging it 'to pledge its opposition to the Uzbek government's forced-labour system.' This is an openly strategic act: the request rests on the expectation of a particular effect and on the readers' understanding of this particular influence mechanism (consumer boycott; loss of custom). The website provides examples of successful petitions and letter writing campaigns to back up the claim of effectiveness in this specific case. In fact, this request is designed to trigger a twostep strategic act: that of putting public pressure on Daewoo, and of Daewoo, in turn, putting pressure on the Uzbek government. 
This is a good point at which to return to the question asked earlier about the assumption of a direct connection between communicative action and the ensuing actions undertaken to cause change in the world (perlocution). It seems now that a better question here is not whether or not accepting an obligation to act leads directly to action, but rather how such an obligation may be translated into predictable forms of action. In the examples above we have seen how the need for profound social change may lead to different forms of engagement, or conversations, as I have called them, and how laying out a range of more specific routes to different actions such as occupations, or letter writing, or fundraising by participating in organized marathons helps to anticipate such differences in engagement and to funnel action into specific activities. Thus, campaigning can be understood as a complex chain of speech acts that include linguistic and nonlinguistic action and produce not only social change, but also campaigning organizations themselves. In this sense, campaigning demands an interplay between producing understanding and producing strategic effectiveness. However, this is a game played simultaneously on more than one field and a game that is never entirely controlled by any of the interlocutors, despite the wish of professional campaigners or strategic communication experts to make us believe otherwise.

\section{Concluding remarks}

In times of rapid change in communication technology and practice, ideas regarded as classics in the discipline of communication can be revisited to interpret and understand the new developments. The key argument made in this paper is that despite technological and theoretical changes, Habermas's communication pragmatics offers a parsimonious framework for understanding of contemporary campaigning for social change, covering both communication and other forms of action repertoires.

This article starts by posing the theoretical disjuncture as a problem shared by a number of communication subfields, such as public communication, public relations, communication for social change, and my particular example, development communication. The more recent scholarship, however, has moved away from this state of knowledge. Instead, scholars highlight the need to embrace nonlinear models, for example of communication for social change (Ciszek 2017; Tufte 2016). In communication for development, effectively, one could argue, that scholars promote hybridity (see Chadwick, 2017) as a way of dealing with the theoretical confusion in the field (Tufte 2016; Wilkins et al. 2014). The analysis presented in this article aims to demonstrate that Habermas's communication pragmatics works well to explicate complex campaigning practices in a consistent and yet theoretically expansive way. Although this analysis is focused narrowly on understanding and 
perlocution as key to campaigning praxis, it is clear that Habermas's thought links also to development communication scholars' preoccupation with agency, justice, and empowerment.

Re-reading Habermas makes it possible to respond to the call articulated by social movement scholars to 'move beyond the limits of strategy (understood as goal-oriented action)' and to recognize the importance of larger cultural conversations and scripts, i.e. the understandings of hidden 'ways of doing things that become routinized as habits, repertoires and traditions' (Doherty, Hayes 2019: 281). Conceptualizing public campaigning as chains of speech acts, defined here as both linguistic and nonlinguistic acts, offers an analytical tool that works across different levels, spaces, and actors involved in social change efforts and that privileges communication as the explanatory mechanism for the contemporary social change praxis.

Finally, at a time when concepts of identity and reputation are treated as central to the construction of collective, organizational voices in the public domain (Edwards 2018: 10), returning to Habermas's work underscores the importance of a valid position, rather than a desirable identity, from which to engage with others in the social world. This invites a clear and consistent focus on action and its basis (moral position) rather than on attributions ascribed to organizations and campaigners (identity). The key question thus shifts from 'Do you like me/trust me sufficiently to follow me?' to the more substantial, 'Is this a good thing to do?'

\section{References}

Austin J. (1962) How to Do Things with Words, Oxford, Oxford University Press.

Baxter H. (2011) Habermas: the Discourse Theory of Law and Democracy, Stanford, CA, Stanford University Press.

Bennett L. and Segerberg A. (2012) The Logic of Connective Action, "Information, Communication \& Society", 15 (5): 739-768.

Cacciottolo M. (2012) Occupy London: What did the St Paul's protest achieve? 28 February. Available at http://www.bbc.co.uk/news/uk-17188327

Chadwick A. (2017) The Hybrid Media System: Politics and Power, $2^{\text {nd }}$ ed., Oxford: Oxford University Press.

Ciszek E. (2017) Activist Strategic Communication for Social Change: A Transnational Case Study of Lesbian, Gay, Bisexual, and Transgender Activism, "Journal of Communication", 67: 702-718. 
Doherty B. and Hayes G. (2019) Tactics and strategic action in: The Wiley Blackwell Companion to Social Movements, D. Snow, S. Soule, H. Kriesi and H. McCammon (eds.), $2^{\text {nd }}$ ed., Oxford, Wiley Blackwell.

Edwards L. (2018) Understanding Public Relations: Theory, Culture and Society, London, Sage.

Fairclough N. (2000) New Labour, New Language?, London, Routledge.

Forchtner B., Krzyzanowski M. and Wodak R. (2013) Mediatization, right-wing populism and political campaigning; the case of Austrian freedom party in: Media Talk and Political Elections in Europe and America, M. Ekstrom and A. Tolson (eds.), Houndsmill, Hampshire, Palgrave Macmillan: 205-228.

Gamson W. and Modigliani A. (1989) Media discourse and public opinion on nuclear power: A Constructionist Approach, "American Journal of Sociology", 95 (1): 1-37.

Green D. (24 February 2012) An Open Letter to the St Paul's Protesters [Blog] New Statesman. Retrieved from http://www.newstatesman.com/blogs/david-allen-green/ 2012/02/city-cathedral-camp-occupy

Habermas J. (1976/2002) What is universal pragmatics? in: On the Pragmatics of Communication, M. Cooke (ed.), Cambridge, Polity: 21-103.

Habermas J. (1984) The Theory of Communicative Action, vol. 1, Cambridge, Polity Press.

Habermas J. (1987) The Theory of Communicative Action, vol. 2, Cambridge, Polity Press.

Habermas J. (1988/2002) Actions, speech acts, linguistically mediated interaction, and the Lifeworld in: On the Pragmatics of Communication, M. Cooke (ed.), Cambridge, Polity: 215-255.

Habermas J. (1996/2002) Some further clarification of the concept of communicative rationality' in: Habermas J. On the Pragmatics of Communication, M. Cooke (ed.), Cambridge, Polity: 307-342.

Hodges D. (28 October 2011) What Occupy LSX are getting wrong [Blog]. Total Politics. Retrieved from at: http://www.totalpolitics.com/blog/268367/what-occupy-lsxare-getting-wrong.thtml

Hallahan K., Holtzhausen D., van Ruler B., Verčič D. and Sriramesh K. (2007) Defining Strategic Communication, "International Journal of Strategic Communication", 1: 3-35. 
Lahausen C. (1996) The Rhetoric of Moral Protest: Public Campaigns, Celebrity Endorsement and Political Mobilization, Berlin, de Gruyter.

Mihelj S. and Stayner J. (2019) Theorizing media, communication and social change: towards a processual approach,"Media, Culture \& Society”, 41 (4): 482-501.

Neuman R. (2016) The Digital Difference: Media Technology and the Theory of Communication Effects, Cambridge, MA: Harvard University Press.

Occupy London Statement [Website] http://occupylondon.org.uk/about-2/ [accessed: 28.05.2014].

Occupy Wall Street [Website] http://occupywallst.org/about/ [accessed: 2.06.2014].

Rice R. and Atkins C. (2013) Public Communication Campaigns, $4^{\text {th }}$ ed, Los Angeles, CA, Sage.

Scannell P. (2007) Media and Communication, Los Angeles, CA, London, Sage.

Schmidt V. (2012) Discursive institutionalism in: The Argumentative Turn Revisited: Public Policy as Communicative Practice, F. Fisher and H. Gottweis (eds.), Durham and London, Duke University Press: 85-113.

Searle J. (1969) Speech Acts, Cambridge, Cambridge University Press.

Sennett R. (2012) Together: The Rituals, Pleasures and Politics of Cooperation, London, Allen Lane.

Smith N. (1997) Strong Hermeneutics: Contingency and Moral Identity, London, Routledge.

Torp S. M. (2015) The Strategic Turn in Communication Science in: The Routledge Handbook of Strategic Communication, D. Holtzhauzen and A. Zerfass (eds.), New York, Routledge: 35-53.

Tufte T. (2017) Communication and Social Change: A Citizen Perspective, Cambridge, UK, Polity Press.

Waisbord S. (2014) The Strategic Politics of Participatory Communication in: The Handbook of Development Communication and Social Change, K. Wilkins T. Tufte and R. Obregon (eds.), Chichester, UK, Wiley Blackwell: 147-167.

Wilkins K., Tufte T. and Obregon R. (eds.) (2014) The Handbook of Development Communication and Social Change, Chichester, UK, Wiley Blackwell.

Witte K. (2000) A meta-analysis of fear appeals: implications for effective public health campaigns, "Health Education and Behavior", 27 (5): 591-615. 


\section{Online resources}

http://www.theguardian.com/uk/2012/feb/28/police-evict-st-pauls-occupyprotesters [accessed: May, 2014].

http://occupylondon.org.uk/occupylsx-general-assembly-minutes-8112011-7pm/ [accessed: May, 2014].

https://www.facebook.com/sosayscotland/ [accessed: May, 2014].

http://issuu.com/sosayscotland/docs/sosayscotland-treasuretrove-thinkin [accessed: May, 2014].

http://www.bbc.co.uk/news/uk-scotland-scotland-politics-20546497 [accessed: May, 2014].

http://cdn.yougov.com/cumulus_uploads/document/vb5ebifzi7/Copy\%20of\%20Re sults\%20120229\%200ccupy\%20London.pdf [accessed: May, 2014].

(http://occupylondon.org.uk/about-2/) [accessed: May, 2014].

(http://occupylondon.org.uk/about-2/) [accessed: May, 2014].

(http://yougov.co.uk/news/2012/02/29/occupy-london-what-impact-has-it-made/ [accessed: May, 2014].

https://www.antislavery.org/wp-content/uploads/2019/03/Anti-Slavery-Accounts2017-18.pdf [accessed: May, 2014].

http://www.europarl.europa.eu/sides/getDoc.do?pubRef=-//EP//TEXT+CRE+ 20111214+ITEM-018+DOC+XML+V0//EN [accessed: May, 2014].

http://www.antislavery.org/english/ [accessed: regularly between June and October 2014]. 